\title{
Augmentation of catecholamine release elicited by an Eugenia punicifolia extract in chromaffin cells
}

\author{
Ricardo de Pascual, ${ }^{1}$ Inés Colmena, ${ }^{1}$ Cristobal de los Rios, ${ }^{1,2}$ \\ Juliana M. Rosa, ${ }^{1}$ Paulo E. Correa-Leite, ${ }^{3}$ Kátia G. Lima- \\ Araújo, ${ }^{4}$ Vitor F. Ferreira, ${ }^{5}$ David R. Rocha, ${ }^{5}$ Daniel T. G. \\ Gonzaga, ${ }^{5}$ Antonio G. García, ${ }^{1,2}$ Wilson C. Santos, ${ }^{1,6}$ Luis \\ Gandía $^{*}, 1$
}

\author{
${ }^{1}$ Instituto Teófilo Hernando, Departamento de Farmacología, Facultad de Medicina, \\ Universidad Autónoma de Madrid, Spain, \\ ${ }^{2}$ Servicio de Farmacología Clínica, Hospital Universitario de la Princesa, Madrid, \\ Spain, \\ ${ }^{3}$ Departamento de Biologia Celular e Molecular, Universidade Federal Fluminense, \\ Brazil, \\ ${ }^{4}$ Departamento de Bromatologia, Faculdade de Farmácia, Universidade Federal \\ Fluminense, Brazil, \\ ${ }^{5}$ Programa de Pós-graduação em Química Orgânica, Instituto de Química, \\ Universidade Federal Fluminense, Brazil, \\ ${ }^{6}$ Departamento de Farmácia e Administração Farmacêutica, Faculdade de \\ Farmácia, Universidade Federal Fluminense, Brazil.
}

\begin{abstract}
Plant extracts of Eugenia punicifolia (Kunth) DC., Myrtaceae, are used in Amazon region of Brazil to treat diarrhea and stomach disturbances, and as hypoglycemic medicine. We have recently shown that an aqueous extract of E. punicifolia augmented cholinergic neurotransmission in a rat phrenic nerve-diaphragm preparation. In this study, we investigated the effects of an $E$. punicifolia dichloromethane extract (EPEX) in a neuronal model of cholinergic neurotransmission, the bovine adrenal chromaffin cell. EPEX augmented the release of catecholamine triggered by acetylcholine (ACh) pulses but did not enhance AChevoked inward currents, which were inhibited by $30 \%$. Since EPEX did not cause a blockade of acetylcholinesterase or butyrylcholinesterase, it seems that EPEX is not directly activating the cholinergic system. EPEX also augmented $\mathrm{K}^{+}$-elicited secretion without enhancing the whole-cell inward calcium current. This novel and potent effect of EPEX in enhancing exocytosis might help to identify the active component responsible for augmenting exocytosis. When elucidated, the molecular structure of this active principle could serve as a template to synthesise novel compounds to regulate the exocytotic release of neurotransmitters.
\end{abstract}

Revista Brasileira de Farmacognosia Brazilian Journal of Pharmacognosy 22(1): 1-12, Jan./Feb. 2012

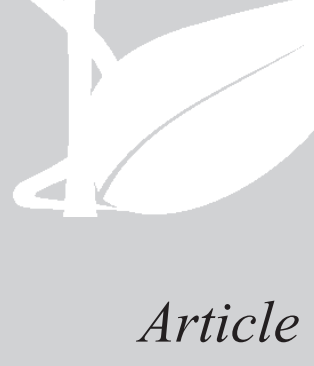

Received 31 Aug 2010

Accepted 3 Mar 2011 Available online 14 Oct 2011

Keywords: calcium channels catecholamine release chromaffin cells Eugenia punicifolia nicotinic receptors

ISSN 0102-695X http://dx.doi.org/10.1590/S0102$695 \times 2011005000191$

\section{Introduction}

Historically, there is a long tradition investigating the pharmacological profile of plant extracts and looking for new active compounds with potential therapeutic interest. This strategy has given rise to many new compounds that lead to the synthesis of new chemical entities to treat several diseases (Marcaurelle \& Johannes, 2008). Our interest is in determining natural product extracts with pharmacological activity, and we recently became interested in studying the cholinergic effects of Eugenia punicifolia (Kunt) DC., Myrtaceae, a plant that grows in the Amazonia forests of Brazil. We studied the effects of a $5 \%(\mathrm{w} / \mathrm{v})$ aqueous extract of $E$. punicifolia on cholinergic neurotransmission at the muscle endplate (rat phrenic nerve-diaphragm preparation), and we found that this extract augmented neurotransmission mediated by nicotinic receptors for acetylcholine (nAChR) (Grangeiro et al., 2006).

Our laboratory has a long-standing interest in the search for compounds with potential capabilities for cholinergic neurotransmission enhancement. With this enhancement, we expect these compounds to improve cognition in Alzheimer's disease (AD) patients, as is the case for galantamine, rivastigmine or donepezil, three inhibitors of acetylcholinesterase (AChE) and 
butyrylcholinesterase (BuChE) (Marco-Contelles et al., 2006; Marco \& do Carmo Carreiras, 2006). For the last decade, we have been designing and synthesising novel hybrid compounds with multi-target profiles, such as inhibiting AChE and/or BuChE, the modulation of $\mathrm{nAChR}$ and neuronal calcium $\left(\mathrm{Ca}^{2+}\right)$ signalling, or neuroprotection against different neurotoxic stimuli (de los Rios et al., 2002; Leon et al., 2005; Orozco et al., 2006; de los Rios et al., 2010). In this context, we hypothesised that the E. punicifolia extract that enhances cholinergic neurotransmission in the rat diaphragm (Grangeiro et al., 2006) could also augment $\mathrm{nAChR}$-mediated catecholamine release responses in adrenal medullary chromaffin cells. This could further stimulate investigations identifying the possible active component(s) in the extract and eventually serve as a starting point for a program synthesising new compounds aimed at optimising the natural active compound.

In this study, we have chosen the chromaffin cell because it is considered an excellent model for studies on basic mechanisms of neuronal communication, $\mathrm{Ca}^{2+}$ signalling, and exocytosis linked to nAChR (Garcia et al., 2006; Livett et al., 2006). We report here that an $E$. punicifolia extract (EPEX) augmented the release of catecholamines from bovine chromaffin cells stimulated with either acetylcholine (ACh) or with high $\mathrm{K}^{+}$ concentrations. In elucidating the mechanisms involved in such augmentation, we also investigated the effects of EPEX on ACh-elicited inward currents $\left(\mathrm{I}_{\mathrm{ACh}}\right), \mathrm{Na}^{+}$ channel currents $\left(\mathrm{I}_{\mathrm{Na}}\right), \mathrm{Ca}^{2+}$ channel currents $\left(\mathrm{I}_{\mathrm{Ca}}\right)$ and cytosolic $\mathrm{Ca}^{2+}$ concentrations $\left(\left[\mathrm{Ca}^{2+}\right]_{\mathrm{c}}\right)$. Furthermore, we also investigated EPEX effects on the activity of both purified AChE and BuChE enzymes.

\section{Material and Methods}

\section{Plant material and preparation of crude extracts}

Eugenia punicifolia (Kunth) DC., Myrtaceae, was kindly supplied by Centro de Instrução de Guerra na Selva (Manaus-AM, Brazil) and was identified at Museu Nacional, UFRJ (Brazil), where voucher specimens were kept for future reference. The official authorisation to investigate this plant was given by Instituto Brasileiro de Meio Ambiente e Recursos Renováveis, Brazil, and it was registered under the number 16602-1. The plant was successively extracted at room temperature with solvents of increasing polarity beginning with $n$-hexane, then dichloromethane and finally methanol. The extracts were concentrated under reduced pressure to yield oily (hexane extract) or solid (dichloromethane and methanol extracts) residues, and they were stored at $4{ }^{\circ} \mathrm{C}$. Stock solutions were prepared at $1 \mathrm{mg} / \mathrm{mL}$ in $10^{-2} \mathrm{M}$ DMSO. Appropriate dilutions of the solutions were made for each experiment. All experiments in this study used the dichloromethane extract (EPEX). Appropriate controls with this solvent were made and no significant effects were observed in the presence of DMSO in any of the experimental protocols (see below) used in this study.

\section{Measurement of AChE activity}

The effect of EPEX on acetylcholinesterase (AChE) activity was determined following the method of Ellman et al. (Ellman et al., 1961) using AChE from Electrophorus electricus (Electric eel; eeAChE) and acetylthiocholine iodide $(0.35 \mathrm{mM})$ as substrate. The reaction took place in a final volume of $3 \mathrm{~mL}$ and consisted of a phosphate buffer solution at $\mathrm{pH} 8.0$ containing $0.035 \mathrm{U}$ of eeAChE and $0.35 \mathrm{mM}$ of $5,5^{\prime}$-dithiobis-2nitrobenzoic acid (DTNB), at $25{ }^{\circ} \mathrm{C}$. The yellow anion 5-thio-2-nitrobenzoic acid is produced as the enzymatic reaction proceeds. After a 10 -min preincubation of the enzyme with different EPEX concentrations, the substrate was added and the enzymatic reaction was allowed to proceed for 15 additional min. A sample without EPEX was always present as a negative control to determine $100 \%$ of enzymatic activity, along with a sample containing $100 \mathrm{nM}$ tacrine as a reference compound (Guillou et al., 2000). After the 15-min incubation period, the production of colour as an indication of enzymatic activity was evaluated by measuring absorbance at 410 $\mathrm{nm}$ in a spectrophotometer plate reader (iEMS Reader MF, Labsystems).

\section{Measurement of BuChE activity}

The effect of EPEX on butyrylcholinesterase (BuChE) was also determined following the method of Ellman et al. (Ellman et al., 1961) using BuChE from horse serum (eqBuChE) and butyrylthiocholine iodide $(0.5 \mathrm{mM})$ as the substrate. The reaction took place at a final volume of $3 \mathrm{~mL}$ and consisted of a phosphate buffer solution at $\mathrm{pH} 8.0$ containing $0.05 \mathrm{U}$ of eqBuChE and $0.35 \mathrm{mM}$ DTNB. The yellow anion 5-thio-2-nitrobenzoic acid is produced as the enzymatic reaction proceeds. The enzyme was pre-incubated for $10 \mathrm{~min}$ with different concentrations of EPEX. After this time, the substrate was added and the enzymatic reaction was allowed to proceed for an additional $15 \mathrm{~min}$, at $25^{\circ} \mathrm{C}$. A sample without EPEX was always present, as a negative control, to determine the $100 \%$ of enzymatic activity, along with a sample containing $100 \mathrm{nM}$ tacrine as a reference compound (Guillou et al., 2000). After the 15-min incubation period, the production of colour as an indication of enzymatic activity was evaluated by measuring absorbance at 410 $\mathrm{nm}$ in a spectrophotometer plate reader (iEMS Reader MF, Labsystems). 
Isolation and culture of adrenal medulla chromaffin cells

Bovine adrenal glands were obtained from a local slaughterhouse. Adrenal medulla chromaffin cells were isolated following standard methods (Livett, 1984) with some modifications (Moro et al., 1990). Cells were suspended in DMEM supplemented with 5\% foetal calf serum, $10 \mu \mathrm{M}$ cytosine arabinoside, $10 \mu \mathrm{M}$ fluorodeoxyuridine, $50 \mathrm{IU} / \mathrm{mL}$ penicillin, and $50 \mu \mathrm{g} / \mathrm{mL}$ streptomycin. For the patch-clamp studies, cells were plated on 1-cm diameter glass coverslips at a low density ( $5 \times 10^{4}$ cells per coverslip). For the catecholamine release measurements, cells were plated on $5-\mathrm{cm}$ diameter Petri dishes at $5 \times 10^{6}$ cells per dish. To study changes in cytosolic $\mathrm{Ca}^{2+}$ levels $\left(\left[\mathrm{Ca}^{2+}\right]_{\mathrm{c}}\right)$, cells were plated at a density of $2 \times 10^{5}$ cells/well in 96-well black dishes.

\section{On-line measurements of catecholamine release}

Bovine chromaffin cells were scrapped off carefully from the bottom of the Petri dishes with a rubber policeman and centrifuged at $800 \mathrm{rpm}$ for $10 \mathrm{~min}$. The cell pellet was resuspended in a $200 \mu \mathrm{L}$ Krebs-HEPES solution at pH 7.4 (in mM: $144 \mathrm{NaCl}, 5.9 \mathrm{KCl}, 1.2 \mathrm{MgCl}_{2}$, 11 glucose, $10 \mathrm{~N}$-(2-hydroxyethyl) piperazine- $N^{\prime}-(2-$ ethanesulfonic acid) (HEPES)). Cells were placed in a microchamber for their superfusion at the rate of $2 \mathrm{~mL} /$ min at $37{ }^{\circ} \mathrm{C}$ in the Krebs-HEPES solution. Under these conditions, the cell superfusion fluid emanating from the microchamber was measured with a thermistor probe and showed a temperature of $35^{\circ} \mathrm{C}$. For the detection of released catecholamines, the liquid flowing from the superfusion chamber reached an electrochemical detector (model CH-9100; Metrohm AG, Herisau, Switzerland) equipped with a glassy carbon working electrode, an $\mathrm{Ag} /$ $\mathrm{AgCl}$ reference electrode and a gold auxiliary electrode. Catecholamines are oxidised at $+0.65 \mathrm{~V}$ and the oxidation current was recorded on a PC computer (Borges et al., 1986).

Cells were stimulated to secrete with short pulses $(5 \mathrm{~s})$ of a Krebs-HEPES solution containing either 35 or $70 \mathrm{mM} \mathrm{K}^{+}$or $100 \mu \mathrm{M}$ acetylcholine, in the absence or presence of different extract concentrations (See Results). Solutions were rapidly exchanged through electrovalves operated by a computer.

\section{Patch-clamp current measurements and analysis}

Inward currents through voltage-gated $\mathrm{Ca}^{2+}$ channels $\left(\mathrm{I}_{\mathrm{Ba}}\right)$, voltage-gated $\mathrm{Na}^{+}\left(\mathrm{I}_{\mathrm{Na}}\right)$, and $\mathrm{nAChR}$ $\left(\mathrm{I}_{\mathrm{ACh}}\right)$ were recorded using the whole-cell configuration of the patch-clamp technique (Hamill et al., 1981). Whole-cell recordings were made with fire-polished electrodes (resistance 2-5 $\mathrm{M} \Omega$ when filled with the standard intracellular solutions) that were mounted on the headstage of an EPC-9 patch-clamp amplifier (Heka Electronic, Lambrecht, Germany), allowing cancellation of capacitative transients and compensation of series resistance. Data were acquired with a sample frequency of $20 \mathrm{kHz}$ by using PULSE 8.74 software (Heka Elektronik, Lambrecht, Germany). Linear leak and capacitative components were substracted by using a $\mathrm{P} / 4$ protocol and series resistance was compensated by $80 \%$. The data analysis was performed with Igor Pro (Wavemetrics, Lake Oswego, OR) and PULSE programs (Heka Elektronik).

Coverslips containing the cells were placed on an experimental chamber mounted on the stage of a Nikon Diaphot inverted microscope. Cells were continuously superfused with a control Tyrode solution at $\mathrm{pH} 7.4$ containing (in $\mathrm{mM}$ ): $137 \mathrm{NaCl}, 1 \mathrm{MgCl}_{2}, 2 \mathrm{CaCl}_{2}, 10$ HEPES/NaOH. Once the patch membrane was ruptured and the whole-cell configuration of the patch-clamp technique had been established, the cell was locally, rapidly and constantly superfused with an extracellular solution of similar composition to the chamber solution, but containing nominally $0 \mathrm{mM} \mathrm{Ca}^{2+}$ to measure $\mathrm{I}_{\mathrm{Na}}, 2$ $\mathrm{mM} \mathrm{Ca}^{2+}$ to measure $\mathrm{I}_{\mathrm{ACh}}$, or $10 \mathrm{mM} \mathrm{Ba}^{2+}$ (instead of $\mathrm{Ca}^{2+}$ ) to measure $\mathrm{I}_{\mathrm{Ba}}$ (see Results for specific experimental protocols). Cells were internally dialysed with an intracellular solution containing (in $\mathrm{mM}$ ): $100 \mathrm{CsCl}, 14$ EGTA, 20 TEA.Cl, $10 \mathrm{NaCl}, 5 \mathrm{Mg}$-ATP, $0.3 \mathrm{Na}-\mathrm{GTP}$, and $20 \mathrm{HEPES} / \mathrm{CsOH}$ ( $\mathrm{pH}$ 7.3). The external solutions were rapidly exchanged using electronically driven miniature solenoid valves coupled to a multi-barrel concentrationclamp device, the common outlet of which was placed within $100 \mu \mathrm{m}$ of the cell to be patched. The flow rate was $1 \mathrm{~mL} / \mathrm{min}$ and regulated by gravity.

Cells were held at $-80 \mathrm{mV} ; \mathrm{Na}^{+}$currents were generated by $15 \mathrm{~ms}$ depolarizing pulses to $-10 \mathrm{mV}, \mathrm{Ba}^{2+}$ currents were generated by $50 \mathrm{~ms}$ depolarizing pulses at 0 or $+10 \mathrm{mV}$; nAChR currents were generated by the application of $250 \mathrm{~ms}$ ACh pulses $(100 \mu \mathrm{M})$. All experiments were performed at room temperature $(24 \pm 2$ ${ }^{\circ} \mathrm{C}$ ) on cells from 2 to 4 days after culture.

\section{Measurement of $\left[\mathrm{Ca}^{2+}\right]_{c}$}

Cells were plated at a density of $2 \times 10^{5}$ cells per well into 96-well plates, and the experiments were performed 48 h later. Cells were loaded with a KrebsHEPES solution at pH 7.4 (in mM: $144 \mathrm{NaCl}, 5.9 \mathrm{KCl}$, $1.2 \mathrm{MgCl}_{2}, 2 \mathrm{CaCl}_{2}, 11$ D-glucose, and 10 HEPES) containing $10 \mu \mathrm{M}$ fluo-4-AM and $0.2 \%$ pluronic acid. The cells were incubated in this solution for $45 \mathrm{~min}$ at $37{ }^{\circ} \mathrm{C}$ in the dark. After this incubation period, cells were washed twice with the Krebs-HEPES solution at room temperature in the dark. Changes in fluorescence (excitation $485 \mathrm{~nm}$, emission $520 \mathrm{~nm}$ ) were measured using a fluorescent plate reader (Fluostar, BMG Labtech, 
Offenburg, Germany). Basal levels of fluorescence were monitored before adding the stimulation solution (containing $100 \mu \mathrm{M}$ acetylcholine) with an automatic dispenser. After stimulation of the cells, changes in fluorescence were measured for $40 \mathrm{~s}$. To normalise fluo- 4 signals, responses from each well were calibrated by measuring maximum and minimum fluorescence values. At the end of each experiment, 3\% Triton X-100 (Fmax) was added followed by $0.2 \mathrm{M} \mathrm{MnCl}_{2}$ (Fmin). Data were calculated as a percentage of Fmax-Fmin.

\section{Reagents}

Collagenase type A from Clostridium histolyticum was purchased from Boehringer-Mannheim (Madrid, Spain). Dulbecco's modified Eagle's medium (DMEM), bovine serum albumin fraction $\mathrm{V}$, foetal calf serum and antibiotics were purchased from Gibco (Madrid, Spain). Collagenase type I from Clostridium histolyticum, 3-aminobenzoic acid ethyl ester, and acetylcholine chloride came from Sigma Chemical Co. (St Louis, MO). The agonist (ACh) was freshly prepared in cold water and diluted to the desired concentration in the extracellular solution.

\section{Data analysis}

The results are presented as mean \pm SE. The measurements of peak current and charge that flow through the channel after its activations were calculated with the program Clampfit 5.03. IC50 values were estimated through non-linear regression analysis using Origin software (OriginLab Corporation, Northampton, USA). Comparisons between means of group data were performed by one-way analysis of variance (ANOVA) followed by the Duncan post-hoc test when appropriate. $p \leq 0.05$ was taken as the limit of significance.

\section{Results}

Effects of EPEX on catecholamine release elicited by repeated ACh pulsing in chromaffin cells

Because EPEX was previously shown to enhance neurotransmission at the muscle endplate (rat phrenic nerve-diaphragm preparation) (Grangeiro et al., 2006), we first explored whether the extract had the capability of augmenting the exocytotic release of catecholamines. Thus, an electrochemical detector working under the amperometric mode was used to measure the real-time rate of catecholamine release from bovine chromaffin cell populations (around 5 million cells per experiment). These cells were trapped in a microchamber and fastperfused with a Krebs-HEPES solution containing $2 \mathrm{mM}$ $\mathrm{Ca}^{2+}$. In each experiment, cells were initially perfused for a 5 to 10 -min period to allow the stabilisation of basal secretion (around $10 \mathrm{nA}$ ). Accumulated experience in our laboratory shows that these cells give highly reproducible amperometric secretory responses upon repeated pulses applied at regular intervals, using solutions containing supramaximal concentrations of ACh (Santos et al., 2001; Cuchillo-Ibáñez et al., 2002; Tapia et al., 2009). We used 3-s pulses of solutions containing $100 \mu \mathrm{M} \mathrm{ACh}$ $(100 \mathrm{ACh})$, which in a previous study were found to fully deplete the ready-releasable vesicle pools under these experimental conditions and produce a maximal peak secretory response (Cuchillo-Ibáñez et al., 2002).

Figure 1A shows a prototypical experiment using repeated 3-s $100 \mathrm{ACh}$ pulses given at 5-min intervals. Note that the peak of the initial secretory spike of $200 \mathrm{nA}$ was maintained fairly constant throughout the experiment. Using this protocol, we surprisingly found that at the low concentration of $0.1 \mathrm{ng} / \mathrm{mL}$, EPEX gradually augmented the ACh-evoked, catecholamine release response, reaching an amplitude 2.5 fold higher than the initial response (Figure 1B). As shown in Figure 1B, basal catecholamine release was not affected by EPEX perfusion; however, upon EPEX washout, the response quickly returned to initial levels and was enhanced once more upon reperfusion of the extract. Pooled data plotted in Figure 1C shows EPEX causing a gradual increase in catecholamine secretion, which was maintained for $15 \mathrm{~min}$ and reversed upon EPEX washout. However, we did not find an obvious concentrationdependence for the secretion-enhancing effects of EPEX that seemed to augment this response even more at 0.1 $\mathrm{ng} / \mathrm{mL}$ than at 1 and $5 \mathrm{ng} / \mathrm{mL}$, although there were no statistical differences between the three concentrations (Figure 1D).

\section{Effects of EPEX on ACh-elicited inward currents}

In trying to elucidate the mechanism involved in the enhancement of ACh-evoked catecholamine release elicited by EPEX, we explored the possibility that the extract was modifying the ACh-elicited inward currents $\left(\mathrm{I}_{\mathrm{ACh}}\right)$. Thus, we performed experiments in voltageclamped cells using the whole-cell configuration of the patch-clamp technique.

Figure $2 \mathrm{~A}$ shows an example of the original $\mathrm{I}_{\mathrm{ACh}}$ obtained upon repeated application of $100 \mu \mathrm{M}$ ACh pulses to the same cell. In this cell, the initial $\mathrm{I}_{\mathrm{ACh}}$ peak amplitude was $968 \mathrm{pA}$. In subsequent $\mathrm{ACh}$ pulses, $\mathrm{I}_{\mathrm{ACh}}$ was maintained fairly well. Figure $2 \mathrm{~B}$ shows a protype experiment in which the initial $\mathrm{I}_{\mathrm{ACh}}$ was reduced by $37 \%$ in the presence of $1 \mathrm{ng} / \mathrm{mLEPEX}$, and this current reduction was readily reversible upon the extract washout. Figure $2 \mathrm{C}$ shows the pooled averaged results of experiments performed in 34 cells. At EPEX concentrations within the range of $0.01-1 \mathrm{ng} / \mathrm{mL}, \mathrm{I}_{\mathrm{ACh}}$ progressively decreased to 
$63 \%$ of the initial current, and higher concentrations (10$100 \mathrm{ng} / \mathrm{mL}$ ) did not produce additional blockade. EPEX washout produced a partial current recovery.

We also tested whether EPEX could affect other ionic channels by measuring the TTX-sensitive sodium current $\left(\mathrm{I}_{\mathrm{Na}}\right)$ in voltage-clamped $(-80 \mathrm{mV})$ cells. We found no effect of EPEX on such current at 0.1 and $1 \mathrm{ng} /$ $\mathrm{mL}$ (data not shown).

\section{Effects of EPEX on the activities of AChE and BuChE}

Since the effects of EPEX in enhancing AChstimulated catecholamine release did not seem to be associated with a direct action on $\mathrm{nAChR}$, we wanted to know whether EPEX affected the activities of two enzymes involved in the rapid degradation of $\mathrm{ACh}$ at synaptic sites, AChE and BuChE (Kutty, 1980; Buchwald,
2001). We performed experiments on the basis of the following previous findings: i) augmentation of synaptic transmission at the muscle endplate elicited by EPEX could be due to inhibition of AChE and BuChE (Grangeiro et al., 2006); ii) drugs inhibiting $\mathrm{AChE}$ and $\mathrm{BuChE}$ have proven to have beneficial effects in Alzheimer's disease patients (Schmidt et al., 2008; van Marum, 2008) and iii) inhibition of $\mathrm{AChE}$ and $\mathrm{BuChE}$ could explain the EPEXelicited augmentation of ACh-evoked catecholamine release responses.

Figure 3 shows the concentration response curves for enzyme inhibition by tacrine, a well-known inhibitor of both AChE and BuChE (Summers et al., 1986). As expected, tacrine inhibited both enzymes in a concentration-dependent manner, with an IC50 for $\mathrm{BuChE}$ at $2.0 \mathrm{nM}$, and $25 \mathrm{nM}$ for $\mathrm{AChE}$. In contrast, the concentrations of EPEX that augmented ACh-evoked
A

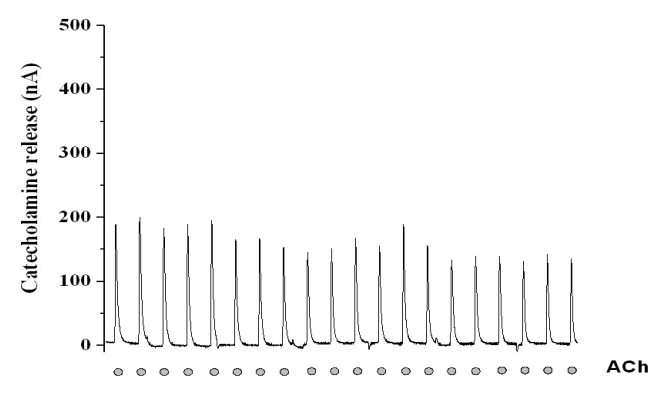

$\mathbf{C}$

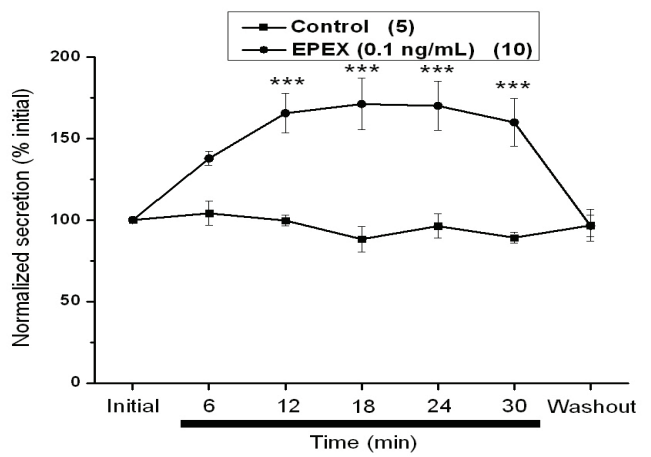

B

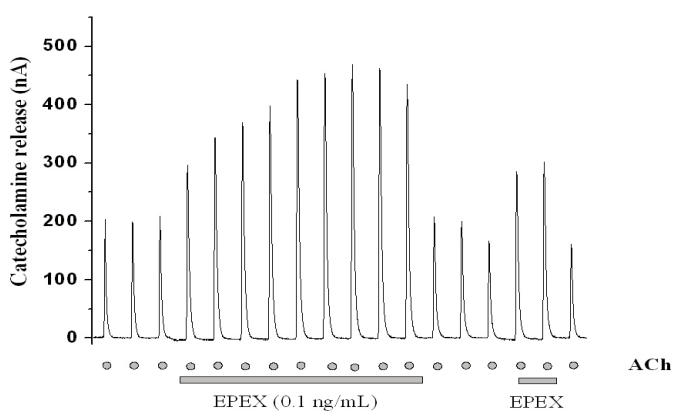

$\mathbf{D}$

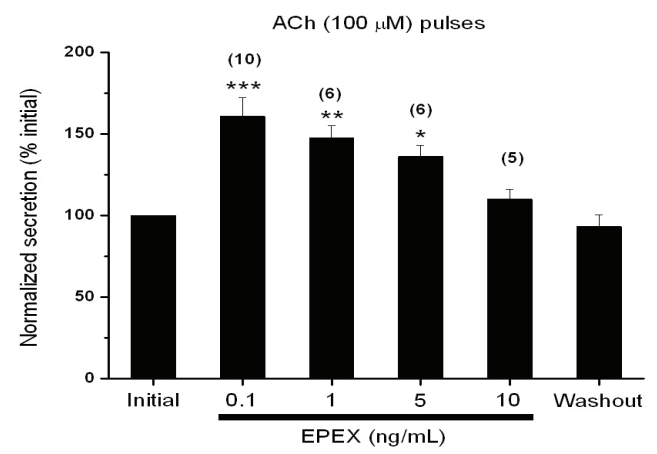

Figure 1. EPEX augments the release of catecholamines triggered by acetylcholine (ACh) pulses. Chromaffin cells $\left(5 \times 10^{6}\right)$ were trapped in a microchamber and perfused with Krebs-HEPES solution. Once stabilised, the basal catecholamine release was between 10 and $20 \mathrm{nA}$. (A) Representative experiment in which cells were stimulated with a solution containing $100 \mu \mathrm{M} \mathrm{ACh}$ for $5 \mathrm{~s}$ at 3-min intervals (dots at the bottom). (B) Cells received three ACh pulses at the beginning of the experiment and then they were perfused with EPEX at $0.1 \mathrm{ng} / \mathrm{mL}$ for the time periods indicated by the two horizontal bars at the bottom. (C) Pooled results of experiments performed with the protocols shown in panel A (control cells) and B (EPEX-treated cells). (D) Effects of increasing concentrations of EPEX given for 30 min on ACh-evoked catecholamine release responses. Data in panels C and D were normalised as the percent of the initial secretion in each individual experiment and are given as mean $\pm \mathrm{SE}$. of the number of experiments shown in parentheses. ${ }^{* *} p<0.005$ and ${ }^{* * *} p<0.001$, with respect to the corresponding control point (panel C) or the initial secretion (panel D). 
secretion (0.1-1 ng/mL, Figure $1 \mathrm{~B}$ and D) or even 1000fold higher concentrations of EPEX, did not affect the activities of AChE or BuChE.

A

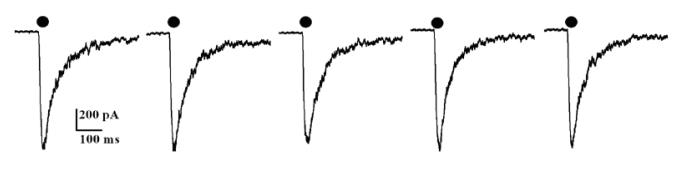

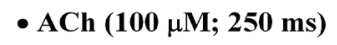

B

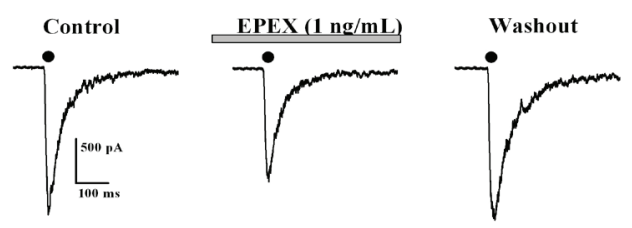

C

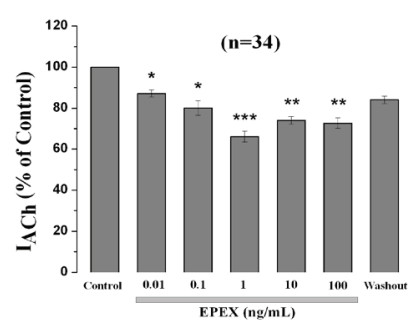

Figure 2. EPEX causes a concentration-dependent mild inhibition of the inward whole-cell current generated by ACh pulses. Cells were voltage-clamped at $-80 \mathrm{mV}$. Upon breaking into the cell, ACh pulses (100 $\mu \mathrm{M}, 250 \mathrm{~ms})$ were sequentially applied to each individual cell at $60 \mathrm{~s}$ intervals. (A) An example cell stimulated with ACh pulses that produced inward $\mathrm{I}_{\mathrm{ACh}}$. (B) An example cell showing the $I_{A C h}$ traces obtained before (initial), $3 \mathrm{~min}$ after perfusion with EPEX, and 3 min after extract washout. (C) Pooled results obtained in cells that were sequentially stimulated with ACh pulses before (initial $\mathrm{I}_{\mathrm{ACh}}$ ) and $3 \mathrm{~min}$ after perfusion with increasing concentrations of EPEX (bottom horizontal bar). Each concentration was tested in a different cell. Data were normalised as the percent of $\mathrm{I}_{\mathrm{ACh}}$ amplitude obtained initially and are represented as mean $\pm \mathrm{SE}$ of 34 cells from five different cultures. ${ }^{*} p<0.05,{ }^{* *} p<0.01$, and ${ }^{* * *} p<0.001$, with respect to initial $\mathrm{I}_{\mathrm{ACh}}$ amplitude.

Effects of EPEX on catecholamine release responses triggered by repeated application of high- $K^{+}$pulses

The sequence of events leading to the coupling between $\mathrm{ACh}$ stimulation and the secretory response (Douglas, 1968) include cell depolarization, opening of voltage-activated $\mathrm{Ca}^{2+}$ channels (VACC) and exocytosis (Garcia et al., 2006). Because EPEX did not seem to augment secretion through a cholinergic-mediated pathway, we explored the possibility that the extract could act on VACC to enhance secretion. We therefore triggered secretion with direct depolarization of the cell membrane with a solution containing $70 \mathrm{mM} \mathrm{K} \mathrm{K}^{+}$ $\left(70 \mathrm{~K}^{+}\right)$. At this concentration, the bovine chromaffin cell membrane potential depolarizes to near $0 \mathrm{mV}$ (Orozco et al., 2006) and opens all VACC (Garcia et al., 2006).

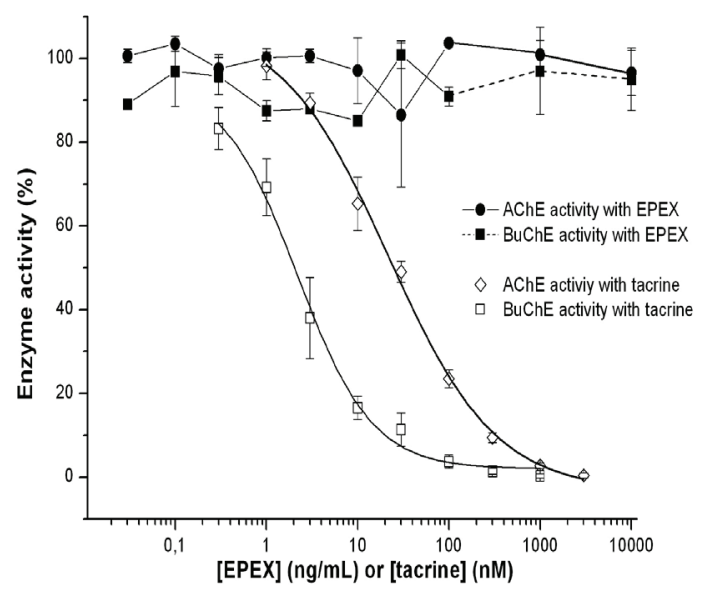

Figure 3. EPEX did not affect the activities of acetylcholinesterase (AChE) and butyrylcholinesterase (BuChE). Purified AChE from Electrophorus electricus or $\mathrm{BuChE}$ from horse serum were incubated with EPEX at the concentrations indicated on the abscissa. Tacrine was used as a positive control. In each individual experiment, the maximal enzyme activities $(100 \%)$ were determined in the presence of vehicle, and enzyme activities were determined in the presence of EPEX or tacrine, expressed as the percent of maximal activity. Data are represented as mean $\pm \mathrm{SE}$ from eight wells from at least two different experiments.

Figure 4A shows the secretory spikes obtained in a representative experiment with cells challenged with repeated $5-\mathrm{s}, 70 \mathrm{mM} \mathrm{K} \mathrm{K}^{+}$pulses given at $3 \mathrm{~min}$ intervals. The initial secretory responses of $200 \mathrm{nA}$ showed an amplitude similar to spikes elicited by ACh pulses (Figure 1A). These responses gradually declined with time to amplitudes of around $70 \%$ of the initial responses. Similar to ACh, EPEX also augmented the $\mathrm{K}^{+}$-evoked responses, and this increase developed more rapidly than with $\mathrm{ACh}$, reaching about 2.5 times the initial spike amplitude (Figures $1 \mathrm{~B}$ and $4 \mathrm{~B}$ ). The reason for such a difference may be explained because we used 5 $\mathrm{ng} / \mathrm{mL}$ EPEX in the $\mathrm{K}^{+}$experiments, a concentration 50 fold higher than that used in the ACh experiments. Figure $4 \mathrm{C}$ shows the pooled results of the effects of EPEX on $\mathrm{K}^{+}$-induced catecholamine secretion. The augmentation of the secretion elicited by EPEX seems to be gradual, similar to that of ACh (Figures $1 \mathrm{C}$ and 4C). Figure 4D shows pooled results of experiments performed with increasing concentrations of EPEX, and the 0.1 and $1 \mathrm{ng} /$ $\mathrm{mL}$ concentrations that enhanced $\mathrm{ACh}$ responses had no effect on the $\mathrm{K}^{+}$responses. In contrast, $5 \mathrm{ng} / \mathrm{mL}$ of EPEX almost doubled the initial $\mathrm{K}^{+}$secretory response. 
Effects of EPEX on inward currents through $\mathrm{Na}^{+}$and $\mathrm{Ca}^{2+}$ channels

High $\mathrm{K}^{+}$concentrations will induce a cell membrane depolarization allowing the opening of voltage-gated $\mathrm{Na}^{+}$channels and VACC to enhance $\mathrm{Ca}^{2+}$ entry, $\left[\mathrm{Ca}^{2+}\right]_{\mathrm{c}}$ and catecholamine secretion. Thus, EPEXelicited enhanced secretion could be due to augmentation of $\mathrm{Ca}^{2+}$ entry through VACC. The most direct way of testing this possibility was measuring the whole-cell inward currents through VACC. Thus, we performed experiments aimed to test the possible effects of EPEX on voltage-gated $\mathrm{Na}^{+}$and $\mathrm{Ca}^{2+}$ channels by recording whole-cell inward currents through these channels.

Figure $5 \mathrm{~A}$ shows original recordings of $\mathrm{I}_{\mathrm{Na}}$ (left panel) and $\mathrm{I}_{\mathrm{Ba}}$ (right panel) elicited by 15 or $50 \mathrm{~ms}$ depolarizing pulses (see protocol on top or the original recordings), in the absence and/or the presence of EPEX $(0.1$ and $1 \mathrm{ng} / \mathrm{mL})$. The peak $\mathrm{Na}^{+}$current density in cells from different batches was $42.15 \pm 6.65 \mathrm{pA} / \mathrm{pF} \quad(\mathrm{n}=8)$ and the peak $\mathrm{Ba}^{2+}$ current density in cells from different batches was $45.63 \pm 4,13 \mathrm{pA} / \mathrm{pF}(\mathrm{n}=15)$. Averaged results obtained with these experimental protocols showed that $\mathrm{I}_{\mathrm{Na}}$ was not significantly modified in the presence of EPEX (left panel in Figure 5B), and only a mild (around 10\%), not significant, decrease of $\mathrm{I}_{\mathrm{Ba}}$ at $0.1-1 \mathrm{ng} / \mathrm{mL}$ EPEX was observed. Figure 5C shows current-voltage curves generated by increasing voltage-step depolarizations. Peak current was reached at $0-+10 \mathrm{mV}$ and was reduced by $5-10 \%$ in the presence of $1 \mathrm{ng} / \mathrm{mL}$ EPEX; however, no shift of the current-voltage (I-V) curve was found during cell treatment with the extract.
A

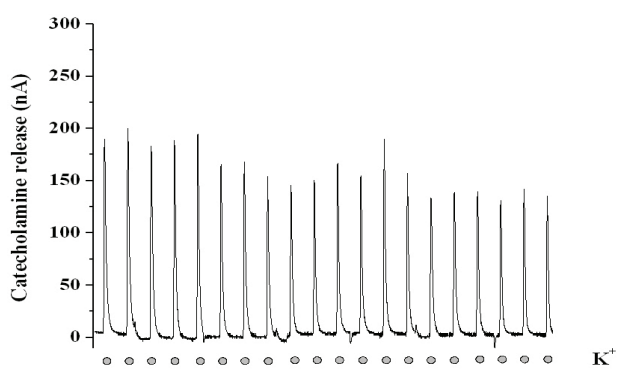

C

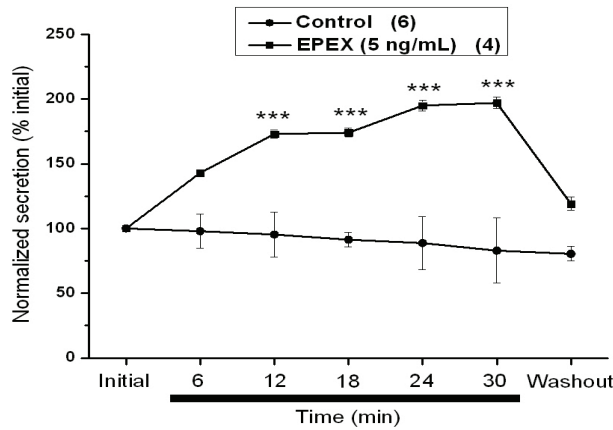

B

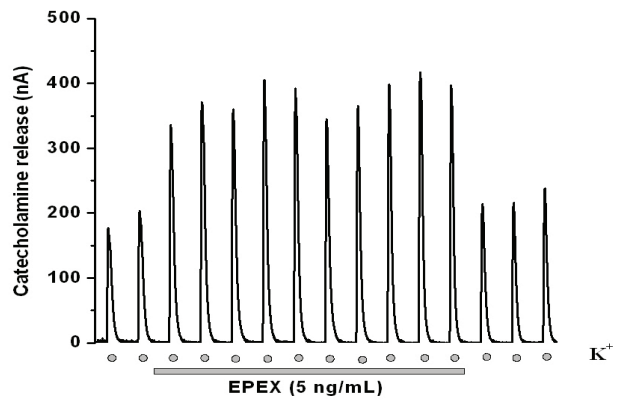

D

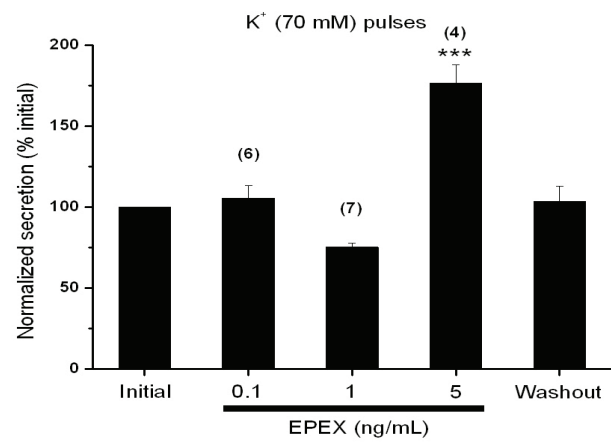

Figure 4. EPEX augmented the release of catecholamines from cells repeatedly stimulated with $\mathrm{K}^{+}$-enriched solutions. Cells were initially perfused with Krebs-Hepes solution and, once baseline secretion was stable, cells were challenged for $5 \mathrm{~s}$ every 3 min with a solution containing $70 \mathrm{mM} \mathrm{K}^{+}$(with low $\mathrm{Na}^{+}$) (dots at the bottom). (A) An example cell showing initial secretion spikes of $200 \mathrm{nA}$. This spike amplitude was maintained during the first five initial pulses and declined by $20 \%$ at the end of the experiment. (B) An example cell perfused with EPEX during the period indicated by the bottom horizontal bar. (C) Pooled data obtained in different experiments made with the protocols shown in panels A (control) and B (EPEX-treated cells). (D) The effects of increasing concentrations of EPEX on $\mathrm{K}^{+}$-evoked secretion. Data in panels $\mathrm{C}$ and D are normalised as a percent of the initial response in each individual experiment and are represented as mean \pm SE. $* * * p<0.001$, with respect to the corresponding time in control cells (panel C) and *** $p<0.001$, with respect to the initial secretion (panel D). 


\section{A}

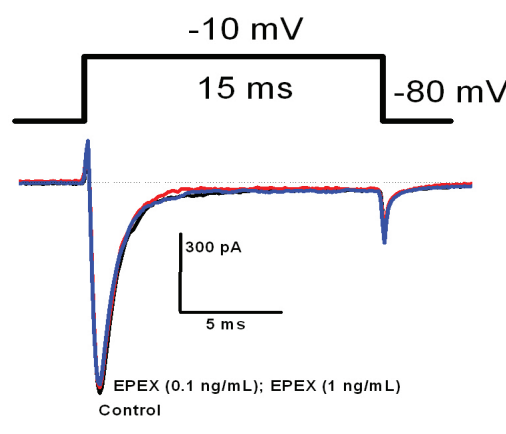

B

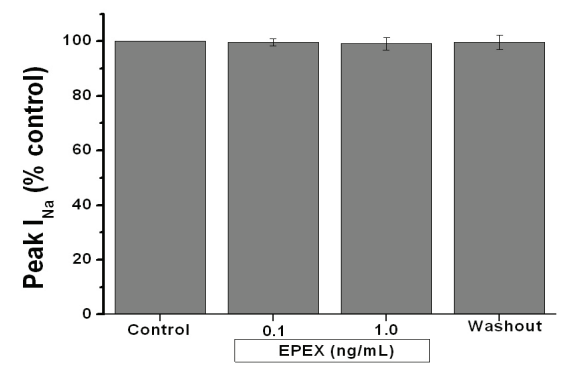

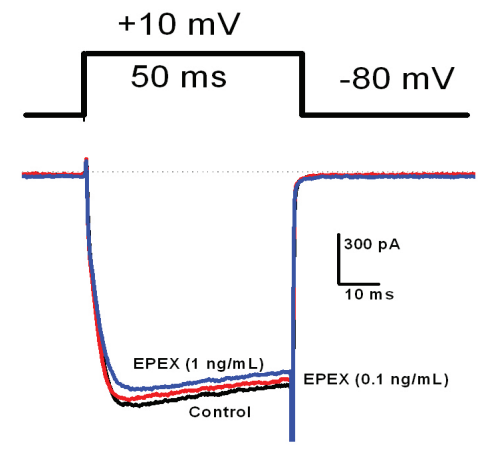

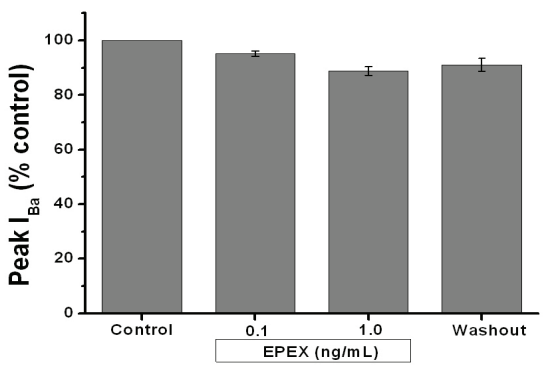

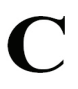

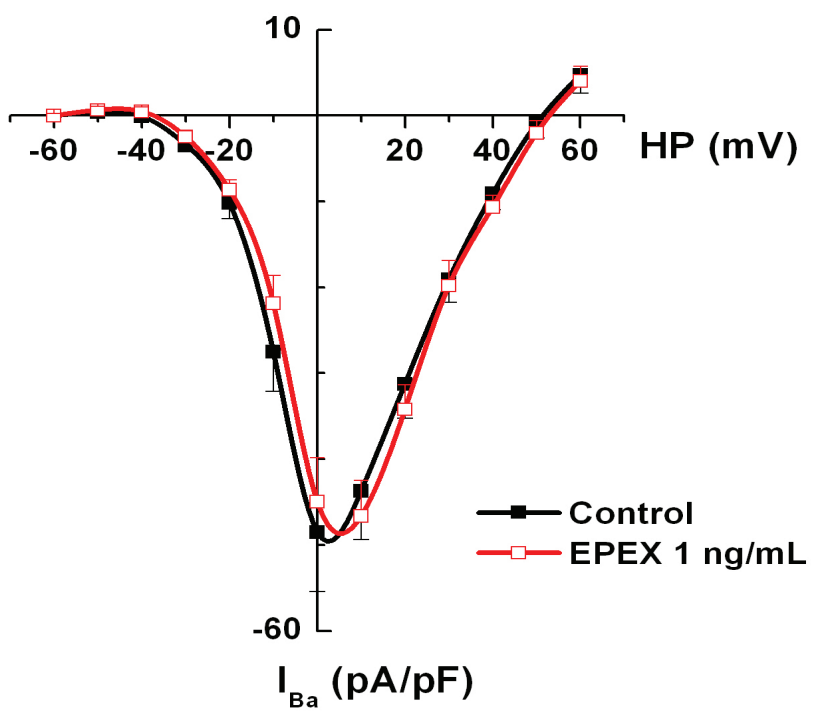

Figure 5. EPEX did not significantly modify the whole-cell inward currents through voltage-gated sodium $\left(\mathrm{I}_{\mathrm{Na}}\right)$ and calcium $\left(\mathrm{I}_{\mathrm{Ba}}\right)$ channels. Cells were voltage-clamped at $-80 \mathrm{mV}$ and step-depolarising pulses (15 $\mathrm{ms}$ to $-10 \mathrm{mV}$ for $\mathrm{I}_{\mathrm{Na}}$, and $50 \mathrm{~ms}$ to $+10 \mathrm{mV}$ for $\mathrm{I}_{\mathrm{Ba}}$; see protocol on top of figure) were sequentially applied at 10-s intervals. Panel (A) shows original recordings of $\mathrm{I}_{\mathrm{Na}}$ (left panel) and $\mathrm{I}_{\mathrm{Ba}}$ (right panel) recorded in the absence and/or the presence of EPEX $(0.1$ and $1 \mathrm{ng} / \mathrm{mL})$. In panel (B) averaged results obtained with these experimental protocols show that $\mathrm{I}_{\mathrm{Na}}$ was not significantly modified in the presence of EPEX (left panel; $\mathrm{n}=8$ ), and only a mild (around 10\%; right panel; $\mathrm{n}=15$ ), not significant, decrease of $\mathrm{I}_{\mathrm{Ba}}$ at $0.1-1 \mathrm{ng} / \mathrm{mL}$ EPEX was observed. Panel (C) shows current-voltage curves generated by increasing voltage-step depolarizations. Peak current was reached at $0-+10 \mathrm{mV}$ and was reduced by $5-10 \%$ in the presence of $1 \mathrm{ng} / \mathrm{mL}$ EPEX ( $\mathrm{n}=11)$;. No shift of the current-voltage $(\mathrm{I}-\mathrm{V})$ curve was found during cell treatment with the extract. Data are mean $\pm \mathrm{SE}$. 
Effects of EPEX on the elevations of cytosolic calcium concentrations $\left(\left[\mathrm{Ca}^{2+}\right]_{c}\right)$ elicited by ACh

In bovine chromaffin cells, ACh pulses cause depolarisation and action potentials that give rise to transient $\left[\mathrm{Ca}^{2+}\right] \mathrm{c}$ elevations (de Diego et al., 2008). Such $\mathrm{Ca}^{2+}$ signals are the result of $\mathrm{Ca}^{2+}$ entry through $\mathrm{nAChR}$ via VACC, or from $\mathrm{Ca}^{2+}$ release from the endoplasmic reticulum (Garcia et al., 2006). Thus, we tested whether EPEX could alter this ACh-elicited $\mathrm{Ca}^{2+}$ signal to explain its ability to augment depolarization-evoked secretion.

Fluo-4-loaded cells were challenged with $\mathrm{ACh}$ pulses in the absence or the presence of increasing concentrations of EPEX. Figure 6A shows two fluorescence records indicating $\left[\mathrm{Ca}^{2+}\right]_{\mathrm{c}}$ elevations elicited by ACh (bottom black horizontal bar), before (left) and during the application of $0.1 \mathrm{ng} / \mathrm{mL}$ EPEX, as indicated by the bottom horizontal grey bar. EPEX slightly augmented the rate and amplitude of the ACh-evoked $\left[\mathrm{Ca}^{2+}\right]_{\mathrm{c}}$ elevation. Pooled results are given in Figure 6A, showing that at 0.1 and $0.3 \mathrm{ng} / \mathrm{mL}$, EPEX augmented the $\left[\mathrm{Ca}^{2+}\right]_{\mathrm{c}}$ elevation by 7 and $12 \%$, respectively (not significant). At greater concentrations, the extract did not change the ACh-evoked $\left[\mathrm{Ca}^{2+}\right]_{\mathrm{c}}$ elevation.

\section{Discussion}

In this study, we found that an extract of the plant E. punicifolia (EPEX) caused an augmentation of catecholamine release from bovine adrenal medullary cells challenged with $\mathrm{ACh}$ (Figure 1) or high $\mathrm{K}^{+}$(Figure 4). Both type of stimuli are widely used to trigger secretion (both induce cell membrane depolarization and subsequently $\mathrm{Ca}^{2+}$ entry through voltage-gated $\mathrm{Ca}^{2+}$ channels, but they differ in the fact that ACh-induced catecholamine secretion implies the activation of nAChR and indirectly depolarize cell membrane, while high $\mathrm{K}^{+}$serves to directly depolarise cell membrane (Garcia et al., 2006). We also used electrophysiological and $\mathrm{Ca}^{2+}$ imaging techniques to determine the mechanisms underlying this potentiation.

Augmentation of ACh-evoked secretion could be due to a direct action of EPEX on nAChR by behaving as an allosteric modulator of $\alpha 7 \mathrm{nAChR}$ (Faghih et al., 2007) that have been identified in bovine chromaffin cells (Quik et al., 1987; Geertsen et al., 1988; Criado et al., 1997; Lopez et al., 1998; Fuentealba et al., 2004). However, this does not seem to be the case because i) EPEX did not augment $\mathrm{I}_{\mathrm{ACh}}$, but it mildly inhibited $\mathrm{I}_{\mathrm{ACh}}$ at concentrations that augmented exocytosis, suggesting that the potentiating effects of EPEX was exerted beyond the nAChR (Figure 2) and ii) EPEX also augmented the $\mathrm{K}^{+}$-evoked secretion (Figure 4), a stimulus that directly depolarises the cells without intervention of nAChR.

In chromaffin cells, the L-subtype VDCC mediates the secretion elicited by $\mathrm{K}^{+}$depolarization, and this response is augmented by the L-type $\mathrm{Ca}^{2+}$ channel activator Bayk 8644 (Garcia et al., 1984). Thus, we considered the possibility that, similar to Bayk 8644, EPEX was acting by enhancing $\mathrm{Ca}^{2+}$ entry through L-channels; however, EPEX mildly reduced $\mathrm{I}_{\mathrm{C}}$ (Figure 5). Although EPEX slightly increased the $\left[\mathrm{Ca}^{2+}\right]$ c elevations induced by $\mathrm{ACh}$, this was not significant (Figure 6). One possibility is that EPEX could augment the quantal content of individual chromaffin vesicles and/ or of the single secretory spike burst, by actin at some of the initial steps of exocytosis. This will be tested in future experiments on quantal catecholamine release at the single cell level, using a carbon fibre microelectrode (Miranda-Ferreira et al., 2008; Miranda-Ferreira et al., 2009)

Although we have not yet uncovered the mechanism of action of EPEX, this study has served to unravel an entirely new biological activity for this plant extract, augmentation of exocytosis. In Brazil, E. punicifolia extracts are employed in Amazon region to treat diarrhea and stomach disturbances, and as hypoglycemic medicine (Brito et al., 2007; Bopp et al., 2009). The mechanism underlying pharmacological properties of the genus Eugenia are partially attributed to flavonoids (myricitrin, quercetin, and quercetrin), steroids, terpenoids, tanines, and anthraquinones (Consolini \& Sarubbio, 2002). We keep doing experiments on the dichloromethane extract used in the presents tudy to gain further information on the composition and to identify the component/s that could be responsible of the observed effects on the cholinergic neurotransmission.

Its use for the treatment of diabetes could be linked to the augmentation of the exocytotic release of insulin in response to hyperglycemia. Also, it is interesting that hypoglycaemic drugs block a type of ATP-dependent potassium channel, and we cannot rule out that a ligand present in the E. punicifolia extract may bind to these potassium channels to elicit an effect. Unfortunately, this type of channel is not present in bovine chromaffin cells and hence we should not explore such possibility. Related to the possibility that EPEX could be acting on other $\mathrm{K}^{+}$ channel types to regulate the catecholamine secretory response, our laboratory found that SK (small conductance calcium-activated $\mathrm{K}^{+}$channels) and BK (big conductance calcium-activated $\mathrm{K}^{+}$channels) were involved in the modulation of exocytosis, due to an indirect effect, by $\mathrm{Ca}^{2+}$ entering through VDCCs (Uceda et al., 1994; Lara et al., 1995). However, we did not find any effect of EPEX on such currents (not shown).

We have discovered a simple and efficient biological test for isolating and chemically characterising the active compound responsible for the potentiation of exocytosis by EPEX. Given the high sensitivity of this test to subnanogram concentrations of EPEX and, since 

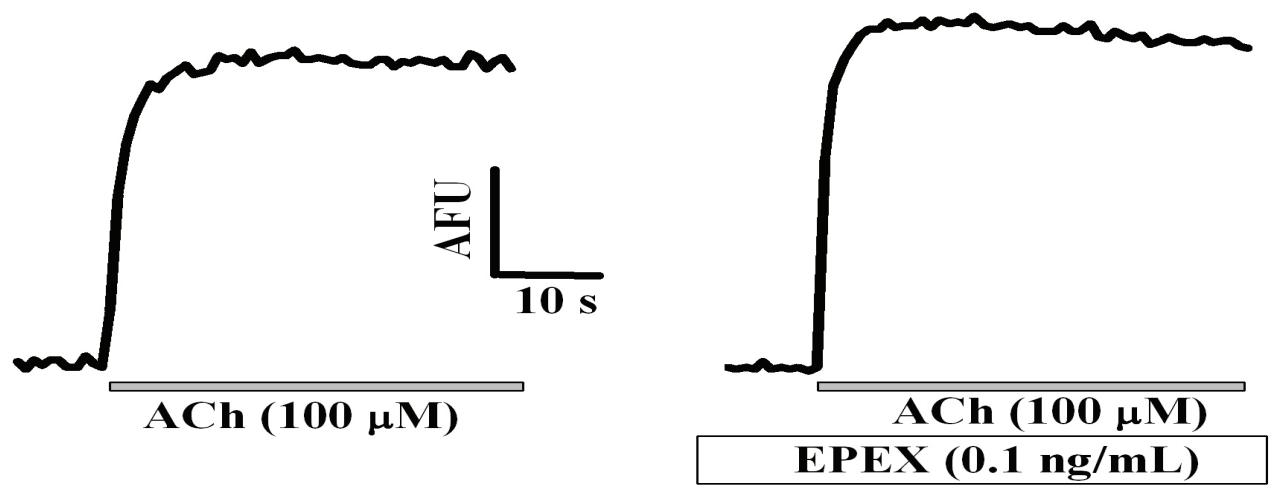

\section{B}

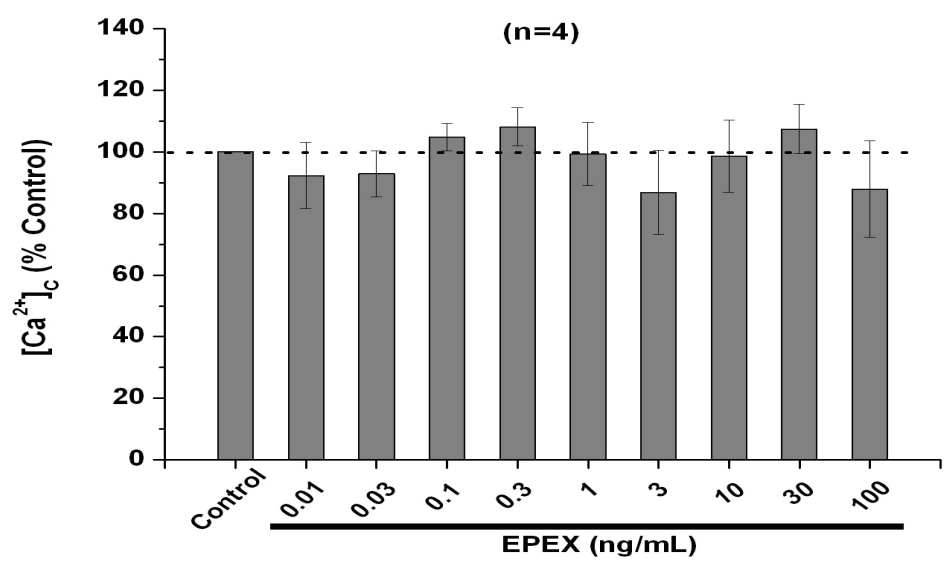

Figure 6. EPEX caused a mild augmentation of cytosolic calcium concentration $\left(\left[\mathrm{Ca}^{2+}\right]_{\mathrm{c}}\right)$ elevations elicited by ACh. Cells loaded with Fluo-4 in a 96-well black plate were challenged with ACh in the absence (control) and the presence of increasing concentrations of EPEX. (A) Original $\left[\mathrm{Ca}^{2+}\right]_{\mathrm{c}}$ traces evoked by ACh in untreated cells (control, left) and cells incubated with $0.1 \mathrm{ng} / \mathrm{mL}$ EPEX, applied $30 \mathrm{~s}$ before and during the incubation period (right). (B) Pooled data from experiments performed with the protocol in panel A. Data are mean \pm SE.

submilligram concentrations are sufficient to analyse exocytotic release of catecholamines from bovine chromaffin cells, testing different fractions of purified extracts can be performed.

In addition to the identification of the active compound in EPEX, our findings have also interested us to search for new biological targets and ligands with potential therapeutic interest in neurodegenerative diseases, particularly in Alzheimer's disease (Rafii \& Aisen, 2009). A compound that augments exocytosis might also enhance neurotransmission, synaptic plasticity and neuronal survival. If the molecular structure of the active compound present in EPEX could eventually be identified, it could become a prototype for the design and synthesis of new compounds capable of improving synaptic plasticity and neuronal communication.
In conclusion, we have discovered that an Eugenia punicifolia extract augments the exocytotic catecholamine release from bovine adrenal chromaffin cells stimulated with $\mathrm{ACh}$ or $\mathrm{K}^{+}$. Using catecholamine release as a biological probe in subsequent studies, could facilitate the isolation of the active compound and the elucidation of its molecular structure. This could be used as a template to synthesise new derivatives with therapeutic potential as cognition enhancers in Alzheimer's disease patients.

\section{Acknowledgements}

This work was partially supported by grants from the Ministerio de Ciencia e Innovación (SAF201021795 to AGG, SAF2010-18837 to LG, and SAB2006- 
0123 to WCS), Comunidad Autónoma de Madrid (S-SAL-0275-2006), and CEAL-SANTANDER (to LG). We thank the Fundación Teófilo Hernando (Spain) and FAPERJ (Brasil) for funding and continued support. Authors are also indebted to Centro de Instrução de Guerra na Selva, Manaus-AM, Brasil, for the provision of plants. WCS, KGLA and VFF are members of the INCT de Processos Redox em Biomedicina funded by CNPq/FAPESP (Brazil).

\section{References}

Bopp A, De Bona KS, Belle LP, Moresco RN, Moretto MB 2009. Syzygium cumini inhibits adenosine deaminase activity and reduces glucose levels in hyperglycemic patients. Fundam Clin Pharmacol 23: 501-507.

Borges R, Sala F, Garcia AG 1986. Continuous monitoring of catecholamine release from perfused cat adrenals. $J$ Neurosci Methods 16: 289-300.

Brito FA, Lima LA, Ramos MF, Nakamura MJ, CavalherMachado SC, Siani AC, Henriques MGMO, Sampaio ALF 2007. Pharmacological study of anti-allergic activity of Syzygium cumini (L.) Skeels. Braz J Med Biol Res 40: 105-115.

Buchwald P 2001. Structure-metabolism relationships: steric effects and the enzymatic hydrolysis of carboxylic esters. Mini Rev Med Chem 1: 101-111.

Consolini AE, Sarubbio MG 2002. Pharmacological effects of Eugenia uniflora (Myrtaceae) aqueous crude extract on rat's heart. J Ethnopharmacol 81: 57-63.

Criado M, Dominguez del Toro E, Carrasco-Serrano C, Smillie FI, Juiz JM, Viniegra S, Ballesta JJ 1997. Differential expression of alpha-bungarotoxin-sensitive neuronal nicotinic receptors in adrenergic chromaffin cells: a role for transcription factor Egr-1. J Neurosci 17: 65546564.

Cuchillo-Ibáñez I, Olivares R, Aldea M, Villarroya M, Arroyo G, Fuentealba J, García AG, Albillos A 2002. Acetylcholine and potassium elicit different patterns of exocytosis in chromaffin cells when the intracellular calcium handling is disturbed. Pflugers Arch 444: 133142.

de Diego AM, Arnaiz-Cot JJ, Hernandez-Guijo JM, Gandia L, Garcia AG 2008. Differential variations in $\mathrm{Ca}^{2+}$ entry, cytosolic $\mathrm{Ca}^{2+}$ and membrane capacitance upon steady or action potential depolarizing stimulation of bovine chromaffin cells. Acta Physiol (Oxf) 194: 97-109.

de los Rios C, Egea J, Marco-Contelles J, Leon R, Samadi A, Iriepa I, Moraleda I, Galvez E, Garcia AG, Lopez MG, Villarroya M, Romero A 2010. Synthesis, inhibitory activity of cholinesterases, and neuroprotective profile of novel 1,8-naphthyridine derivatives. J Med Chem 53: 5129-5143.

de los Rios C, Marco JL, Carreiras MD, Chinchon PM, Garcia AG, Villarroya M 2002. Novel tacrine derivatives that block neuronal calcium channels. Bioorg Med Chem 10: 2077-2088.

Douglas WW 1968. Stimulus-secretion coupling: the concept and clues from chromaffin and other cells. $\mathrm{Br} J$ Pharmacol 34: 453-474.

Ellman GL, Courtney KD, Andres V, Jr., Feather-Stone RM 1961. A new and rapid colorimetric determination of acetylcholinesterase activity. Biochem Pharmacol 7: 88-95.

Faghih R, Gfesser GA, Gopalakrishnan M 2007. Advances in the discovery of novel positive allosteric modulators of the alpha7 nicotinic acetylcholine receptor. Recent Pat CNS Drug Discov 2: 99-106.

Fuentealba J, Olivares R, Ales E, Tapia L, Rojo J, Arroyo G, Aldea M, Criado M, Gandi L, Garci AG 2004. A cholineevoked $\left[\mathrm{Ca}^{2+}\right]_{\mathrm{c}}$ signal causes catecholamine release and hyperpolarization of chromaffin cells. Faseb J 18: 14681470.

Garcia AG, Garcia-De-Diego AM, Gandia L, Borges R, GarciaSancho J 2006. Calcium signaling and exocytosis in adrenal chromaffin cells. Physiol Rev 86: 1093-1131.

Garcia AG, Sala F, Reig JA, Viniegra S, Frias J, Fonteriz R, Gandía L 1984. Dihydropyridine BAY-K-8644 activates chromaffin cell calcium channels. Nature 309: 69-71.

Geertsen S, Afar R, Trifaro JM, Quik M 1988. Regulation of alpha-bungarotoxin sites in chromaffin cells in culture by nicotinic receptor ligands, $\mathrm{K}^{+}$, and cAMP. $\mathrm{Mol}$ Pharmacol 34: 549-556.

Grangeiro MS, Calheiros-Lima AP, Martins MF, Arruda LF, Garcez-do-Carmo L, Santos WC 2006. Pharmacological effects of Eugenia punicifolia (Myrtaceae) in cholinergic nicotinic neurotransmission. J Ethnopharmacol 108: 26-30.

Guillou C, Mary A, Renko DZ, Gras E, Thal C 2000. Potent acetylcholinesterase inhibitors: design, synthesis and structure-activity relationships of alkylene linked bisgalanthamine and galanthamine-galanthaminium salts. Bioorg Med Chem Lett 10: 637-639.

Hamill OP, Marty A, Neher E, Sakmann B, Sigworth FJ 1981. Improved patch-clamp techniques for high-resolution current recording from cells and cell-free membrane patches. Pflugers Arch 391: 85-100.

Kutty KM 1980. Biological function of cholinesterase. Clin Biochem 13: 239-243.

Lara B, Zapater P, Montiel C, de la Fuente MT, Martinez-Sierra R, Ballesta JJ, Gandía L, García AG 1995. Density of apamin-sensitive $\mathrm{Ca}\left({ }^{2+}\right)$-dependent $\mathrm{K}^{+}$channels in bovine chromaffin cells: relevance to secretion. Biochem Pharmacol 49: 1459-1468.

Leon R, Marco-Contelles J, Garcia AG, Villarroya M 2005. Synthesis, acetylcholinesterase inhibition and neuroprotective activity of new tacrine analogues. Bioorg Med Chem 13: 1167-1175.

Livett BG 1984. Adrenal medullary chromaffin cells in vitro. Physiol Rev 64: 1103-1161. 
Livett BG, Sandall DW, Keays D, Down J, Gayler KR, Satkunanathan N, Khalil Z 2006. Therapeutic applications of conotoxins that target the neuronal nicotinic acetylcholine receptor. Toxicon 48: 810-829.

Lopez MG, Montiel C, Herrero CJ, Garcia-Palomero E, Mayorgas I, Hernandez-Guijo JM, Villarroya M, Olivares R, Gandía L, McIntosh JM, Oliveira BM, García AG 1998. Unmasking the functions of the chromaffin cell alpha7 nicotinic receptor by using short pulses of acetylcholine and selective blockers. Proc Natl Acad Sci U S A 95: 14184-14189.

Marcaurelle LA, Johannes CW 2008. Application of natural product-inspired diversity-oriented synthesis to drug discovery. Prog Drug Res 66: 187-216.

Marco-Contelles J, do Carmo Carreiras M, Rodriguez C, Villarroya M, Garcia AG 2006. Synthesis and pharmacology of galantamine. Chem Rev 106: 116133.

Marco L, do Carmo Carreiras M 2006. Galanthamine, a natural product for the treatment of Alzheimer's disease. Recent Pat CNS Drug Discov 1: 105-111.

Miranda-Ferreira R, de Pascual R, Caricati-Neto A, Gandia L, Jurkiewicz A, Garcia AG 2009. Role of the endoplasmic reticulum and mitochondria on quantal catecholamine release from chromaffin cells of control and hypertensive rats. $J$ Pharmacol Exp Ther 329: 231-240.

Miranda-Ferreira R, de Pascual R, de Diego AM, Caricati-Neto A, Gandia L, Jurkiewicz A, García AG 2008. Singlevesicle catecholamine release has greater quantal content and faster kinetics in chromaffin cells from hypertensive, as compared with normotensive, rats. $J$ Pharmacol Exp Ther 324: 685-693.

Moro MA, López MG, Gandía L, Michelena P, García AG 1990. Separation and culture of living adrenaline- and noradrenaline-containing cells from bovine adrenal medullae. Anal Biochem 185: 243-248.

Orozco C, Garcia-de-Diego AM, Arias E, Hernandez-Guijo JM, Garcia AG, Villarroya M, López MG 2006. Depolarization preconditioning produces cytoprotection against veratridine-induced chromaffin cell death. Eur $J$
Pharmacol 553: 28-38.

Quik M, Geertsen S, Trifaro JM 1987. Marked up-regulation of the beta-bungarotoxin site in adrenal chromaffin cells by specific nicotinic antagonists. Mol Pharmacol 31: 385-391.

Rafii MS, Aisen PS 2009. Recent developments in Alzheimer's disease therapeutics. BMC Med 7: 7.

Santos WC, Hernandez-Guijo JM, Ruiz-Nuno A, Olivares R, Jurkiewicz A, Gandia L, García AG 2001. Blockade by agmatine of catecholamine release from chromaffin cells is unrelated to imidazoline receptors. Eur J Pharmacol 417: 99-109.

Schmidt R, Neff F, Lampl C, Benke T, Anditsch M, Bancher C, Dal-Bianco P, Reisecker F, Marksteiner J, Rainer M, Kepeller P, Dodel R 2008. Therapy of Alzheimer's disease: current status and future development. Neuropsychiatr 22: 153-171.

Summers WK, Majovski LV, Marsh GM, Tachiki K, Kling A 1986. Oral tetrahydroaminoacridine in long-term treatment of senile dementia, Alzheimer type. $N$ Engl J Med 315: 1241-1245.

Tapia L, Garcia-Eguiagaray J, Garcia AG, Gandia L 2009. Preconditioning stimuli that augment chromaffin cell secretion. Am J Physiol Cell Physiol 296: C792-800.

Uceda G, Artalejo AR, de la Fuente MT, Lopez MG, Albillos A, Michelena P, Garcia AG, Montiel C 1994. Modulation by L-type $\mathrm{Ca}^{2+}$ channels and apamin-sensitive $\mathrm{K}^{+}$ channels of muscarinic responses in cat chromaffin cells. Am J Physiol 266: C1432-1439.

van Marum RJ 2008. Current and future therapy in Alzheimer's disease. Fundam Clin Pharmacol 22: 265-274.

\section{*Correspondence}

\section{Luis Gandía}

Instituto Teófilo Hernando de I+D del Medicamento, Facultad de Medicina, Universidad Autónoma de Madrid

Arzobispo Morcillo, 4; 28029 Madrid, Spain

luis.gandia@uam.es

Tel.: 34914975396

Fax: 34914973680 